\title{
PLASMA CATECHOLAMINE LEVELS DURING EXTRACORPOREAL CIRCULATION IN CHILDREN
}

\author{
M. Yamashita, S. Wakayama, A. Matsuki, M. Kudo and T. Oyama
}

\begin{abstract}
Agstract
Plasma adrenaline and noradrenaline concentrations have been measured in nine children undergoing cardiac operations involving extracorporeal circulation under neuroleptanaesthesia.

Compared to control values, plasma adrenaline increased 34-fold and noradrenaline, 2.2-fold during extracorporeal circulation.

The increase in plasma catecholamines reported in adults has been confirmed in these children and changes in plasma adrenaline concentrations during extracorpareal circulation were found to be much greater in paediatric patients.
\end{abstract}

Key Words: Paediatric ANAesthesia; catecholamines, extracorporeal circulation.

\section{INTRODUCTION}

EXTRACORPOREAL circulation has been referred to as "controlled shock". Increases of plasma levels of "stress hormones", including catecholamines, ${ }^{1-9}$ vasopressin ${ }^{8,10,11}$ and growth hormone ${ }^{12}$ during extracorporeal circulation have been reported in adults. However, little information is available regarding the hormonal responses to extracorporeal circulation in children. The authors have measured plasma adrenaline and noradrenaline concentrations during open heart operations in children to elucidate catecholamine responses to extracorporeal circulation.

\section{METHOD}

\section{Subjects}

Nine children, six boys and three girls, ranging in age from two to eight years (mean $4.9 \pm$ 0.8 ) and weighing 11.0 to $43.5 \mathrm{~kg}$ (mean $18.2 \pm$ 3.3) who underwent open-heart operations under extracorporeal circulation, were the subjects of our study. Informed consent was obtained from their parents. Six operations were closures of VSD, two closures of ASD, and one repair of pulmonary stenosis.

\section{Anaesthesia}

Hyoscine $0.01 \mathrm{mg} \cdot \mathrm{kg}^{-1}$ and morphine 0.02

M. Yamashita, M.D., S. Wakayama, M.D., A. Matsuki, M.D., M. Kudo, M.D. T. Oyama, M.D. Department of Anesthesiology, Hirosaki University School of Medicine, Hirosaki; Japan.

Can. Anaesth. Soc. J., vol. 29, no. 2, March 1982
$0.03 \mathrm{mg} \cdot \mathrm{kg}^{-1}$ were administered intramuscularly 60 minutes before induction of anaesthesia with halothane (two per cent maximum) combined with nitrous oxide and oxygen 70:30 in small children, or with droperidol $1.5 \mathrm{mg} \mathrm{kg}^{-1}$, fentanyl $5 \mu \mathrm{g} \cdot \mathrm{kg}^{-1}$ and thiopentone $2-3 \mathrm{mg} \cdot \mathrm{kg}^{-1}$ in older children. Tracheal intubation was done with the aid of succinylcholine chloride and maintenance was with droperidol $3.9 \pm 0.7 \mathrm{mg}$, fentanyl $326 \pm 48 \mu \mathrm{g}$ and d-tubocurarine $20.4 \pm$ $2.1 \mathrm{mg}$.

\section{Extracorporeal circulation}

A.C.D. blood, lactated Ringer's solution and mannitol were used as priming solution, and haematocrit was adjusted between 20 and 30 per cent. Extracorporeal circulation was maintained with a bubble-type oxygenator (Shiley S070) under non-pulsatile flow with moderate hypothermia $\left(30-32^{\circ} \mathrm{C}\right)$. Duration of extracorporeal circulation ranged from 36 to 108 minutes (mean $63 \pm 7.2)$

\section{Sampling}

Six ml of whole blood was drawn from the arterial line at eight sampling times. These were as follows: S1, control, just after arterial cannulation; S2, immediately before skin incision; S3, immediately before extracorporeal circulation (ECC); S4, five minutes ECC; S5, 20 minutes ECC; S6, 40 minutes ECC; S7, 30 minutes after termination of $\mathrm{ECC}$; $\mathrm{S} 8$, in the recovery room. The samples were centrifuged immediately and the plasma was stored at 126 
$-20^{\circ} \mathrm{C}$ until analysis. Blood samples were assayed for adrenaline and noradrenaline using a modification of the method of Anton et al. ${ }^{13}$ with high speed liquid chromatography. Coefficients of variations of adrenaline and noradrenaline were 10.8 and 7.0 per cent, respectively. The minimum sensitivity of both hormones was $30 \mathrm{pg}$.

Student's t-test was used for statistical analysis, and $P<0.05$ was regarded as statistically significant.

\section{RESULTS}

Mean plasma concentration of adrenaline at $\mathrm{S}_{1}$ (control) was $86.4 \pm 23.9$ (S.E.) $\mathrm{pg} / \mathrm{ml}$ and with surgical stress $\left(S_{3}\right)$ the concentration increased 3.5-fold. With start of extracorporeal circulation a marked increase in adrenaline concentrations was observed, being 7.1, 24.4 and 34.0-fold compared with the control values at 5 minutes $\left(S_{4}\right), 20$ minutes $\left(S_{5}\right)$, and 40 minutes $\left(S_{6}\right)$, respectively. The concentration decreased after the termination of extracorporeal circulation, but still remained above control values (Figure 1).

Mean plasma concentration of noradrenaline was $217.8 \pm 48.8$ (S.E.) $\mathrm{pg} / \mathrm{ml}$ at $S_{1}$ (control). A slight increase in the concentration was observed during extracorporeal circulation these being

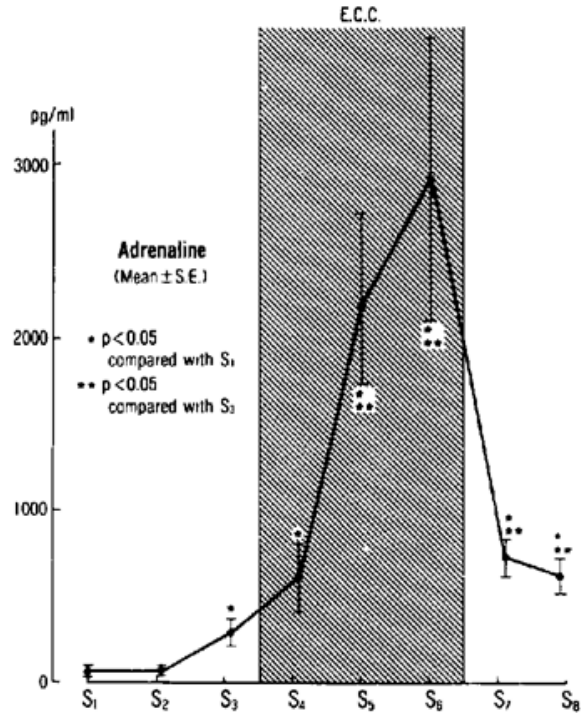

FIGURE 1 Changes in plasma adrenaline levels during open heart operations in children.
TABLE I

SAmpling Times

$S_{1}$ : Control; just after arterial cannulation

$S_{2}$ : Immediately before skin incision

$\mathrm{S}_{3}$ : Immediately before extracorporeal circulation (ECC)

$S_{4}$ : At 5 minutes ECC

$S_{5}$ : At 20 minutes ECC

$S_{6}$ : At 40 minutes ECC

$\mathrm{S}_{7}: 30$ minutes after termination of extracorporeal circulation

$\mathrm{S}_{\mathrm{g}}$ : In the recovery room

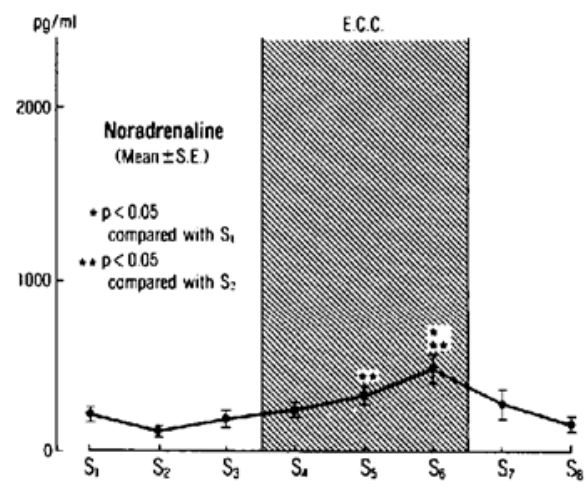

FIGURE 2 Changes in plasma noradrenaline levels during open heart operations in children.

$1.1,1.5$ and 2.2 times the control values at 5 minutes $\left(S_{4}\right), 20$ minutes $\left(S_{5}\right)$, and 40 minutes $\left(\mathrm{S}_{6}\right)$, respectively (Figure 2 ).

\section{Discussion}

Increase in plasma catecholamines during extracorporeal circulation in children was observed in our study. Increase of plasma catecholamines during extracorporeal circulation in adults has been reported during anaesthesia with nitrous oxide-thiopentone-gallamine, ${ }^{1}$ diethyl ether, ${ }^{2}$ halothane, ${ }^{3}$ enflurane, ${ }^{4}$ morphine, ${ }^{4-7}$ neurolept anaesthesia ${ }^{7,8}$ and massive doses of fentanyl. ${ }^{9}$

Others have reported that there was no increase in plasma catecholamine concentrations during extracorporeal circulation in adults anaesthetized with halothane, ${ }^{2}$ neurolept anaesthesia ${ }^{14}$ and phenoperidine or fentanyl combined with less than 0.5 per cent halothane. ${ }^{15}$ However, little is known about catecholamine responses to extracorporeal circulation in children.

Anton, et $a l^{2}$ reported a greater urinary adrenaline excretion in children following car- 
diac operations under extracorporeal circulation than in adults, and suggested that this might be due to a greater adrenaline response. Satoh ${ }^{16}$ observed a 33 -fold increase in plasma adrenaline concentration during extracorporeal circulation under neurolept-anaesthesia in ten children with a mean age of eight years.

Changes in plasma noradrenaline concentrations in our study were much less marked than those for adrenaline, as reported both in adults ${ }^{1,2,4,5-9,14,15}$ and children. ${ }^{16}$ Differences in noradrenaline response to extracorporeal circulation between adults and children seems to be minimal.

The dominant response of adrenaline in children is interesting, since the ratio of adrenaline to noradrenaline in the adrenal medulla increases with age, and 80 per cent of catecholamines in the adrenal venous blood in the adult is adrenaline. ${ }^{17}$

Several theories have been advanced to explain the rise in catecholamine during extracorporeal circulation. They include hypotension at the start of extracorporeal circulation ${ }^{4-6,14}$ lightening of anaesthesia by haemodilution, ${ }^{18}$ hypothermia, ${ }^{5}$ inadequate tissue perfusion, ${ }^{19}$ differences in pulsatile and non-pulsatile flow ${ }^{20}$ and greater stress from the extracorporeal circulation than from the surgical intervention. ${ }^{9}$ Tan, et al. ${ }^{4}$ reported that the recovery of blood pressure following initial hypotension at the start of extracorporeal circulation under morphine anaesthesia was parallelled by an increase of plasma catecholamines, and they postulated that the initial hypotension might trigger catecholamine release. Stanley, et al. ${ }^{9}$ observed that large doses of fentanyl $\left(75 \mu \mathrm{g} \cdot \mathrm{kg}^{-1}\right)$ prevented the rises of plasma cortisol, adrenaline, noradrenaline, and dopamine caused by surgical stress, but it did not prevent the increase of adrenaline, noradrenaline and dopamine brought about by the stress from the extracorporeal circulation. They suggested therefore that the magnitude of stress from extracorporeal circulation is much greater than that produced by surgery.

The exact mechanism of the rise in catecholamines during extracorporeal circulation is not clear, but it is clear that it is not physiological and represents a severe stress to children.

\section{REFERENCES}

1. Replogle, R., LeVy, M., DeWall, R.A., etal. Catecholarnine and serotonin response to car- diopulmonary bypass. J. Thorac. Cardioyasc. Surg. 44: 638-648 (1962)

2. Anton, A.H., Gravenstein, J.S. \& Wheat, M.W., JR. Extracorporeal circulation and endogenous epinephrine and norepinephrine in plasma, atrium, and urine in man. A comparison of ether and halothane anesthesia. Anesthesiology 25: 262-269 (1964)

3. NinOMiYa, J. Studies on endogenous catecholamines during extracorporeal circulation. J. Jap. Assac. Thorac. Surg. 25: 1164-1177 (1977).

4. TAN, C., Glisson, S.N., El-ETr, A.A., et al. Adrenal responses to anesthetics during cardiopulmonary bypass. Cardiovasc. Med. 3: 521528 (1978).

5. Hirvonen, J., Huttunen, P., Nuutinen, L., et al. Catecholamines and free fatty acids in plasma of patients undergoing cardiac operations with hypothermia and bypass. J. Clin. Path. 3I: 949-955 (1978).

6. Balasaraswathi, K, Glisson S.N., El-Etr, A.A., et al. Serum epinephrine and norepinephrine during valve replacement and aorto-coronary bypass. Can. Anaesth. Soc. J. 25: 198-203 (1978).

7. Matsumoto, H., Yoshitake, T., Makuuchi, H. \& SaEGUSA, M. Study on alternations in the metabolism of catecholamines after open heart surgery - The first report: Depletion of endogenous dopamine, noradrenaline and adrenaline. J. Jap. Assoc. Thorac. Surg. 27: 1524-1536 (1979).

8. Matsuki, A., Ishimara, H., Tsugo, T., et al. Plasma levels of ADH and catecholamines during cardiopulmonary bypass in man. Jap. J. Anesth. 28: $1549-1555$ (1979)

9. Stanley, T.H., Berman, L., Green, O., et al. Plasma catecholamine and cortisol responses to fentanyl-oxygen anesthesia for coronary-artery operations. Anesthesiology 53: 250-253 (1980).

10. Philbin, D.M., Coggins, C.H., Wilson, N., et al. Antidiuretic hormone levels during cardiopulmonary bypass. J. Thorac. Cardiovasc. Surg. 73: 145-148 (1977).

11. Philbin, D.M. \& Coggins, C.H. Plasma vasopressin levels during cardiopulmonary bypass with and without profound haemodilution. Can. Anaesth. Soc. J. 25: 282-285 (1978).

12. MACDONALD, R.G., BuCKIER, J.M.H., DeverALL, P.B., et al. Growth hormone and blood glucose concentrations during cardiopulmonary bypass. Brit. Jour. Anaes. 47: 713-718 (1975).

13. ANTON, A.H. \& SAYRE, D.F. A study of factors affecting the aluminum oxide trihydroxyindal procedure for the analysis of catecholamine. $J$. Pharmacol. 138: 360-375 (1962).

14. TAN, C., Glisson, S.N., El-ETr, A.A., et al. Levels of circulating norepinephrine and epinephrine before, during, and after cardiopulmonary bypass in man. $\mathbf{J}$. Thorac. Cardiovasc. Surg. 71: 928-931 (1976).

15. HINE, I.P., WOOD, W.G., MaINWARINGBURGON, R.W., et al. The adrenargic response to surgery involving cardiopulmonary bypass, as measured by plasma and urinary catecholamine concentrations. Brit. Jour. Anaes. 48: 355-363 (1976). 
16. SАтон, K. Effect of dibutyryl cyclic AMP on hemodynamics and metabolism of carbohydrates and lipid after extracorporeal circulation in cardiac surgical patients. J. Jap. Assoc. Thorac. Surg. 28: 425-437 (1980).

17. Symington, T. Functional pathology of the human adrenal gland. London. E. \& S. Living. stone (1969)

18. LONG, D.M., TODD, D.B., INDEGLIA, R.A., et al. Clinical use of dextran- 40 in extracorporeal circulation. Transfusion 6: 401-419 (1966).

19. Gilston, A. Anaesthesia for cardiac surgery. Brit. Jour. Anaes. 43: 217-232 (1971).

20. TRinkle, J.K., Helton, N.E., WoOd, R.E., et al. Metabolic comparison of a new pulsatile pump and a roller pump for cardiopulmonary bypass. J. Thorac. Cardiovasc. Surg. 58: 562569 (1969).

\section{RESUME}

On a mesuré les concentrations plasmatiques d'adrénaline et de noradrenaline sur neuf enfants opérés pour une chirurgie cardiaque sous circulation extra-corporelle et neuroleptanesthésie.

Lorsque comparée aux valeurs de contrôle, l'adrénaline plasmatique a augmenté de 34 fois et la noradrénaline de 2.2 fois pendant la circulation extracorporelle.

On confirme donc sur l'enfant l'augmentation des catécholamines plasmatiques déjà rapportée chez l'adulte avec cette différence que l'augmentation est beaucoup plus grande chez le malade pédiatrique. 